\title{
Stent Placement for the Treatment of Complex Internal Carotid Bifurcation Aneurysms: A Review of 16 Cases
}

\author{
Kompleks Internal Karotid Bifurkasyon Anevrizmalarının Tedavisi İçin \\ Stent Yerleştirme: 16 Olgunun Gözden Geçirilmesi
}

Yu ZHOU, Peng-Fei YANG, Bo HONG, Wen-Yuan ZHAO, Qing-Hai HUANG, Qiang LI, Yi-Bin FANG, Rui ZHAO, Yi XU, Jian-Min LIU

Changhai Hospital, Department of Neurosurgery, Shanghai, China

Correspondence address: Jian-Min LIU / E-mail: liu118@vip.163.com

\begin{abstract}
AIM: Stent placements for the treatment of complex internal carotid bifurcation aneurysms are not well documented yet. In this article, we reported a series of 16 such cases to evaluate the feasibility, safety and effectiveness of stent placement for these particular lesions.

MATERIAL and METHODS: Between June 2001 and August 2011, 16 patients with 16 ICA bifurcation aneurysms were treated by stent assisted coiling at our institution. Their clinical data, treatment results and follow-up were retrospectively collected and analyzed.

RESULTS: Sixteen stents, including 10 Enterprise, 4 Neuroform, 1 Solitaire and 1 one balloon-mounted coronary stent (BX), were successfully deployed in this series. Immediate angiogram showed complete occlusion in 5, neck remnant in 2 and residual sac in 9 . No procedure-related complication occurred. Angiographic follow-up results (mean, 12.1months) were available in 15 patients, 9 of the aneurysms were cured, 1 was improved, 3 were stable, 2 were recanalized, and 1 was retreated. Clinical follow-up (mean, 28.6months) of all 16 patients demonstrated no neurologic deterioration or rebleeding.
\end{abstract}

CONCLUSION: Our result suggests that stent placement for the treatment of complex ICA bifurcation aneurysms is feasible and safe. However, its efficacy should be further evaluated by larger case series and more adequate follow-up.

KEYWORDS: Endovascular treatment, Internal carotid artery, Aneurysm, Stent

öz

AMAÇ: Kompleks internal karotid bifurkasyon anevrizmaları için stent yerleştirme hakkında iyi bilgi yoktur. Bu makalede bu tür 16 vakayı bu lezyonlar için stent yerleştirmenin kullanılabilirliği, güvenliği ve etkinliğini değerlendirmek üzere bildiriyoruz.

YÖNTEM ve GEREÇLER: Haziran 2001 ile Ağustos 2011 arasında IKA bifurkasyon anevrizmaları olan 16 hasta kurumumuzda stent yardımlı sarmal koyma yoluyla tedavi edildi. Klinik verilerin tedavi sonuçları ve takipleri retrospektif olarak toplanıp analiz edildi.

BULGULAR: 10 Enterprise, 4 Neuroform, 1 Solitaire ve 1 balona monte edilmiş koroner stent (BX) dahil olmak üzere 16 stent bu seride başarıly yerine yerleştirildi. Hemen yapılan anjiyogram 5 'inde tam oklüzyon, 2'sinde kalan boyun kısmı ve 9'unda rezidüel kese gösterdi. Işlemle ilgili komplikasyon oluşmadı. Anjiyografik takip sonuçları (ortalama 12,1 ay) 15 hastada mevcuttu ve anevrizmaların 9'u tamamen iyileşmişti, 1'i daha iyiydi, 3'ü stabildi, 2'sinde tekrar kanalizasyon vardı ve 1'i tekrar tedavi edildi. Klinik takip (ortalama 28,6 ay) 16 hastanın hiçbirinde nörolojik bozulma veya tekrar kanama göstermedi.

SONUÇ: Sonucumuz kompleks IKA bifurkasyon anevrizmaları için stent yerleştirmenin kullanılabilir ve güvenli olduğunu düşündürmektedir. Ancak etkinliği daha büyük vaka serilerinde ve yeterli takiple daha ileri olarak değerlendirilmelidir.

ANAHTAR SÖZCÜKLER: Endovasküler tedavi, İnternal karotid arter, Anevrizma, Stent

\section{INTRODUCTION}

Since ISAT investigators published their results, more and more aneurysms are treated via the endovascular approach (17). This is especially true for internal carotid artery (ICA) bifurcation aneurysms since clipping is challenging due to its deep locations and vital perforators surrounding or adherent to the aneurysms $(8,11,16)$.
However, this kind of bifurcation aneurysms often harbor unfavorable morphologies (wide-necked or fusiform) and/ or incorporate branches, which may limit the usage of endovascular embolization $(7,22)$. In recent years, various techniques emerged to help overcome this difficulty. Of them, intracranial stent is one of the most promising tools. Nevertheless, articles concerning the usage of stent for ICA bifurcation aneurysms are still few. 
We retrospectively collected and analyzed our data of 16 aneurysms with complex morphologies treated by stentassisted coiling. The purpose of this article is to evaluate the feasibility, safety and effectiveness of stent placement for these particular lesions when using different stents and different stenting strategies.

\section{MATERIAL and METHODS}

Between June 2001 and August 2011, 31 patients harboring 31 ICA bifurcation aneurysms were treated at our institution. This makes up $1.56 \%(31 / 1989)$ of all the patients treated at the same time. Of these patients, 15 patients were treated by coils alone, while the other 16 patients with 16 wide-necked or fusiform ICA bifurcation aneurysms were treated by stentassisted coiling due to the complex morphologies of the aneurysms.

Of the 16 patients treated by stent-assisted coiling, there were 9 men and 7 women with a mean age of 50.6 years (range 34-66 years). Of the 16 aneurysms, 8 were acutely ruptured, 7 were unruptured, and 1 was retreated due to recanalization.

Of the 8 patients with a ruptured aneurysm, Hunt and Hess $(\mathrm{HH})$ grade scale when admitted to hospital was $\mathrm{HH} \mathrm{I}$ in 2 patients, and $\mathrm{HH}$ II in 6 . Endovascular treatments were performed by several authors of this article (J.L, Y.X., B.H., W.Z and $Q . H$, who had more than 5 years of experience).

\section{Aneurysm Morphology}

Of 16 aneurysms, five were located on the left side and 11 on the right. Four were fusiform aneurysms, and the other 12 were saccular. These 16 aneurysms were classified into 4 types according to the position of the aneurismal neck relative to the carotid T (22): The aneurismal necks were symmetrical on the top of the bifurcation in 9, A1 dominance in 2, M1 dominance in 3, and ICA dominance in 2.

For the 16 aneurysms, the aneurysms size ranged from 2.5 to $13.1 \mathrm{~mm}$. According to their size, two were classified as tiny aneurysms ( $\leq 3 \mathrm{~mm}), 11$ were small ( $3-10 \mathrm{~mm}$ ), and 4 were large ( $\geq 10 \mathrm{~mm}$ ). Of them, five aneurysms with a sac size $\leq 5$ $\mathrm{mm}$ underwent EVT because of rupture $(n=3)$ and SAH from another intracranial aneurysm $(n=2)$. All of the 12 saccular aneurysms were defined to be wide-neck aneurysms as having a large neck ( $\geq 4 \mathrm{~mm}$ ) and/or a dome-to-neck ratio $\leq 2$. Moderate stenosis in the proximal segment of ICA terminus was observed in 1 patient. No calcification in the region of the aneurysm, or partial intrasaccular thrombosis was observed on DSA, CT, or MR imaging. Five patients had multiple aneurysms.

\section{Procedures}

All patients with acutely ruptured aneurysms were treated within 3 days of admission. All procedures were performed with the patient under general anesthesia and via the transfemoral approach.

After confirming the ICA bifurcation aneurysms, neckpressing tests were conventionally performed to check the compensation of blood supply via anterior communicating arteries. And then the stents were deployed following the standard procedure recommended by the manufacturer. All stents were deployed into M1 segment except for one in which the stent was deployed into A1 segment.

Four types of stents were used in this series, including Neuroform stents (Boston Scientific/Target, Fremont, California), Enterprise stents (Cordis), Solitaire ${ }^{\mathrm{TM}} A B$ stent (ev3, Irvine, $C A$, USA) and one balloon-mounted coronary stent (BX-Velocity, Cordis) (Figure $1 \mathrm{~A}-\mathrm{F}$ ).

Stenting strategies applied in our series were as follows: 1) Stenting before coiling. The stent was first deployed to bridge the aneurysm neck in 5 aneurysms. Then microcatheter was positioned into the aneurysm sac through the meshes of the stent, through which the coils were introduced (Figure $2 \mathrm{~A}-\mathrm{E}$ ). 2) Stenting after coiling. In 9 patients, the stents were partially (semi-jailing) (Figure $3 \mathrm{~A}-\mathrm{F}$ ) or fully deployed (modified-jailing) (Figure $4 \mathrm{~A}-\mathrm{F}$ ) to cover the aneurismal neck after introducing part of the framing coils. And then additional coils were introduced through the "jailed" microcatheter to embolize the aneurysms. One patient received staged stent placement 1 month after initial coiling due to worrying about further treatment of external ventricular drainage. Besides, "bailout" strategy was used in the other 1 patient.

\section{Anticoagulation and Antiplatelet Management}

All patients received systemic heparinization after placement of the sheath. The activated clotting time was maintained at 2-3 times the baseline throughout the procedure. Lowmolecular-weight heparin ( $40 \mathrm{mg}$, every 12 hours, hypodermic injection) was administered immediately after the procedure for 3 days. For patients with unruptured aneurysms, dual antiplatelet drugs $(75 \mathrm{mg} /$ day of clopidogrel and $300 \mathrm{mg} /$ day of aspirin) were given for 3 days before the procedure. For patients with acutely ruptured aneurysms, a loading dose of clopidogrel and aspirin (300 mg each) was administered orally or rectally at 2 hours before stent placement. All patients were continued on aspirin and clopidogrel postoperatively for 6 weeks followed by aspirin alone, which was maintained indefinitely.

\section{Clinical and Angiographic Follow-Up}

All patients were advised to be clinically evaluated 1, 3, 6, and 12 months after the treatment and yearly thereafter. Postoperative angiographicfollow-up was also recommended, including 3-month MR angiography and 6-month DSA. The angiographic results were interpreted independently by 2 authors (Y.Z and P.Y), and were classified into four categories when compared with the immediate embolization degree: 1 ) Completely occluded, defined as no contrast filling into the aneurysm sac; 2) Improved, defined as decreased contrast filling into the aneurysm sac; 3) Stable, defined as unchanged contrast filling into the aneurysm sac; 4) Recanalized, defined as the increased contrast filling into the aneurysm sac. 

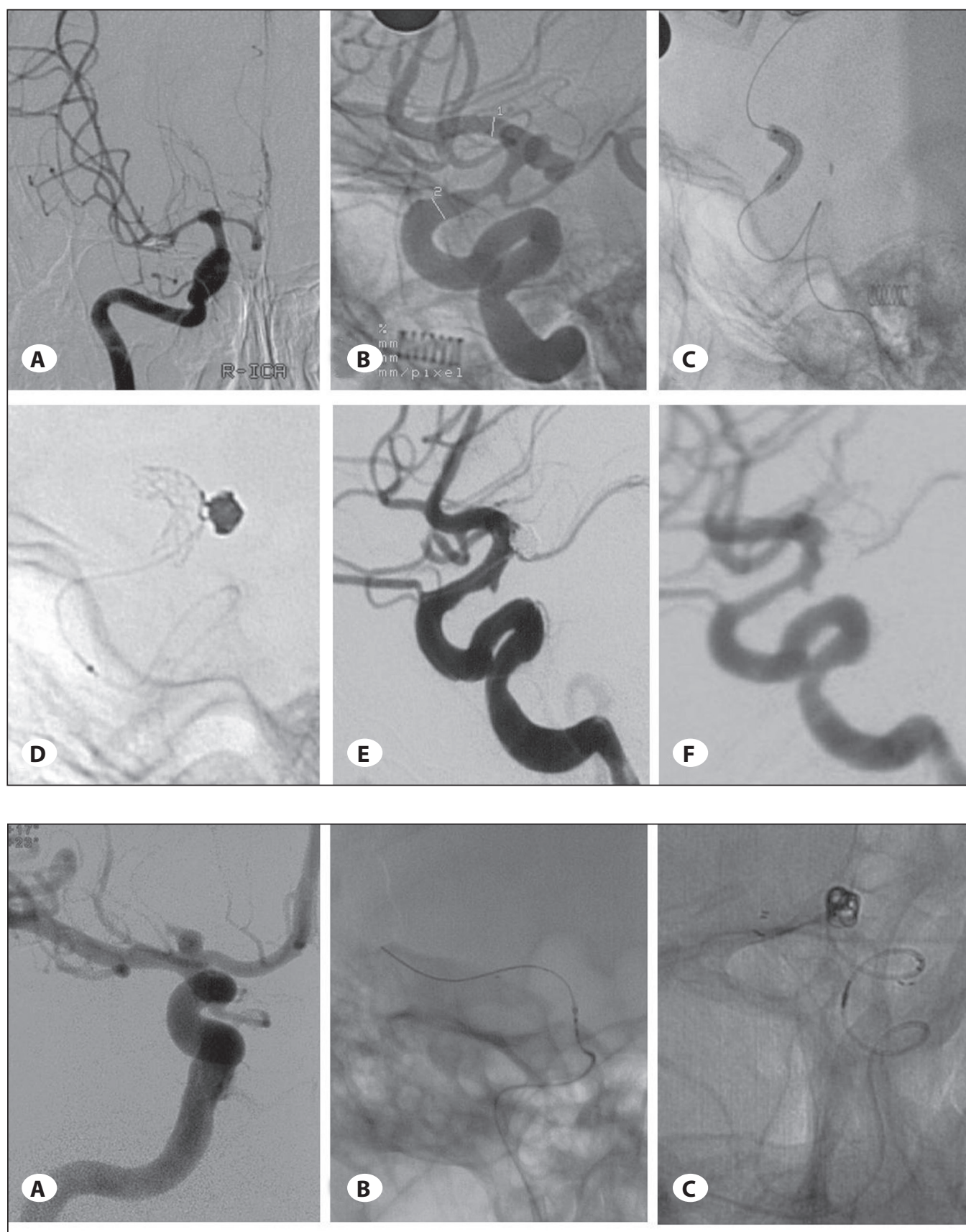

A


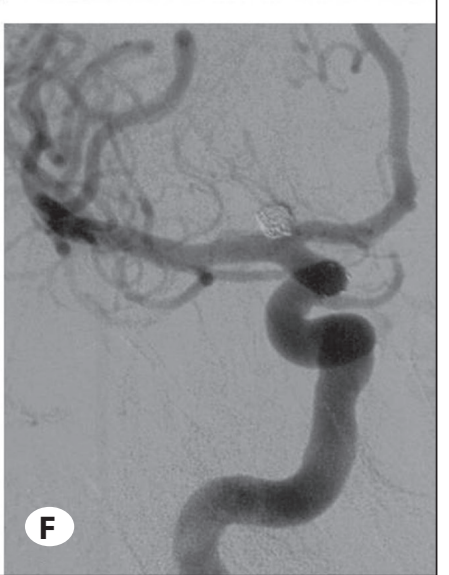

Figure 1: Images of patient 1 treated with a balloonmounted coronary stent. Pre-operative angiogram shows an ICA bifurcation aneurysm pointing posterior, moderate stenosis in the proximal segment of ICA terminus is also observed (A-B). A balloon-mounted coronary stent is first deployed (C), coils are then introduced through the mesh of the stent (D). Post-operative angiogram shows a neck remnant of the aneurysm. Angiogram 24 months later shows the aneurysm is cured (E), and the stenosis is improved (F).

Figure 2: Images of patient 6 treated with Mesh technique. Pre-operative angiogram shows an ICA bifurcation aneurysm (A). During the procedure, a Neuroform stent is first deployed into MCA (B), the patient is then treated with Mesh technique (C). Post-operative angiogram shows complete occlusion of the aneurysm (D). Angiogram 26 months later shows the aneurysm remain completely occluded (E). 

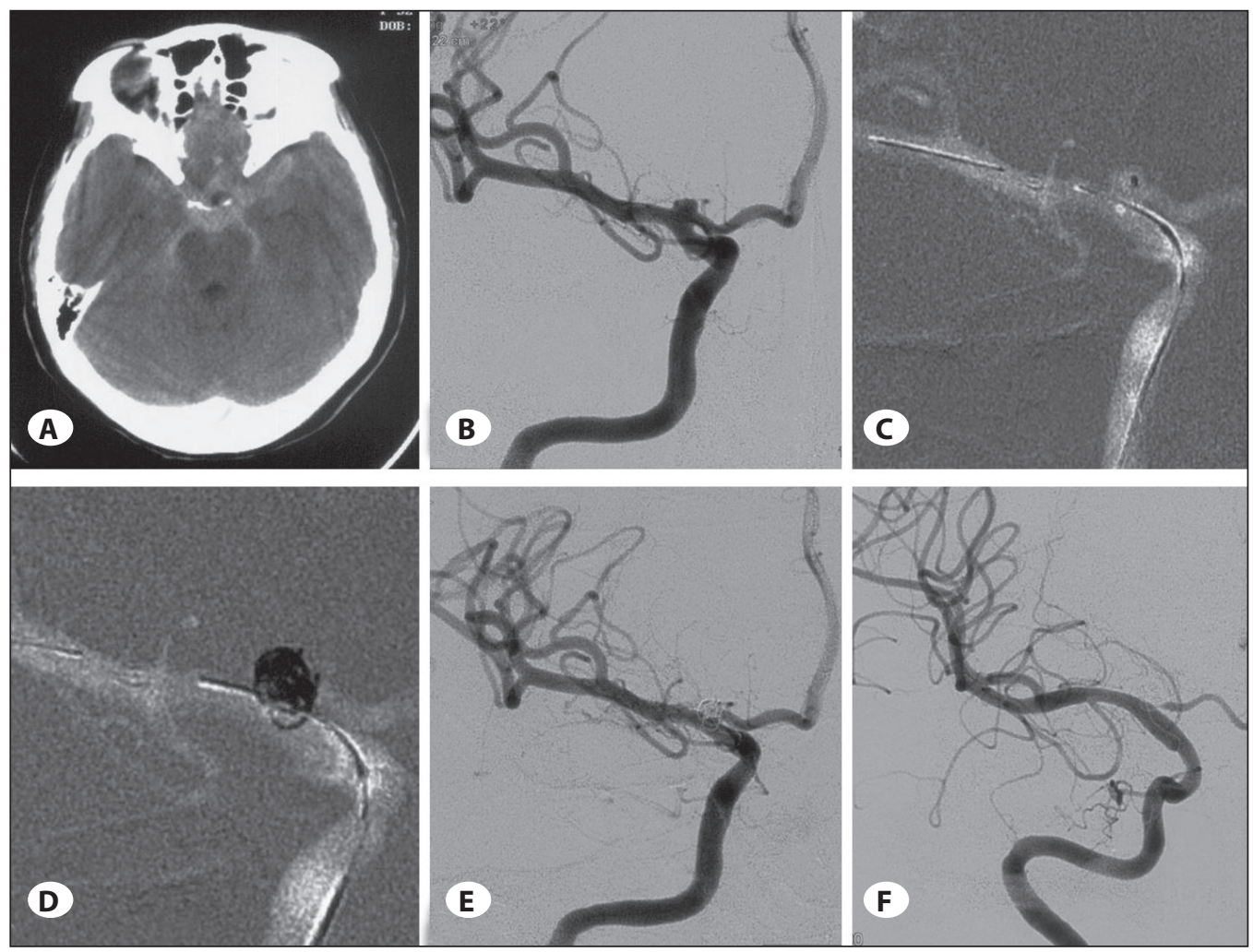

Figure 3 Images of patient 7 who was presented with SAH confirmed by an (A) axial CT scan. Angiogram reveals an ICA bifurcation aneurysm (B). During the operation, an Enterprise stent is partially deployed to bridge part of the aneurismal neck (C), and then additional coils are introduced through the narrowed aneurysm sac to embolize the aneurysm (D). Finally, the aneurysm is subtotally occluded (E). Angiogram 7 months later shows complete occlusion of the aneurysm with patency of the parent vessels (F).
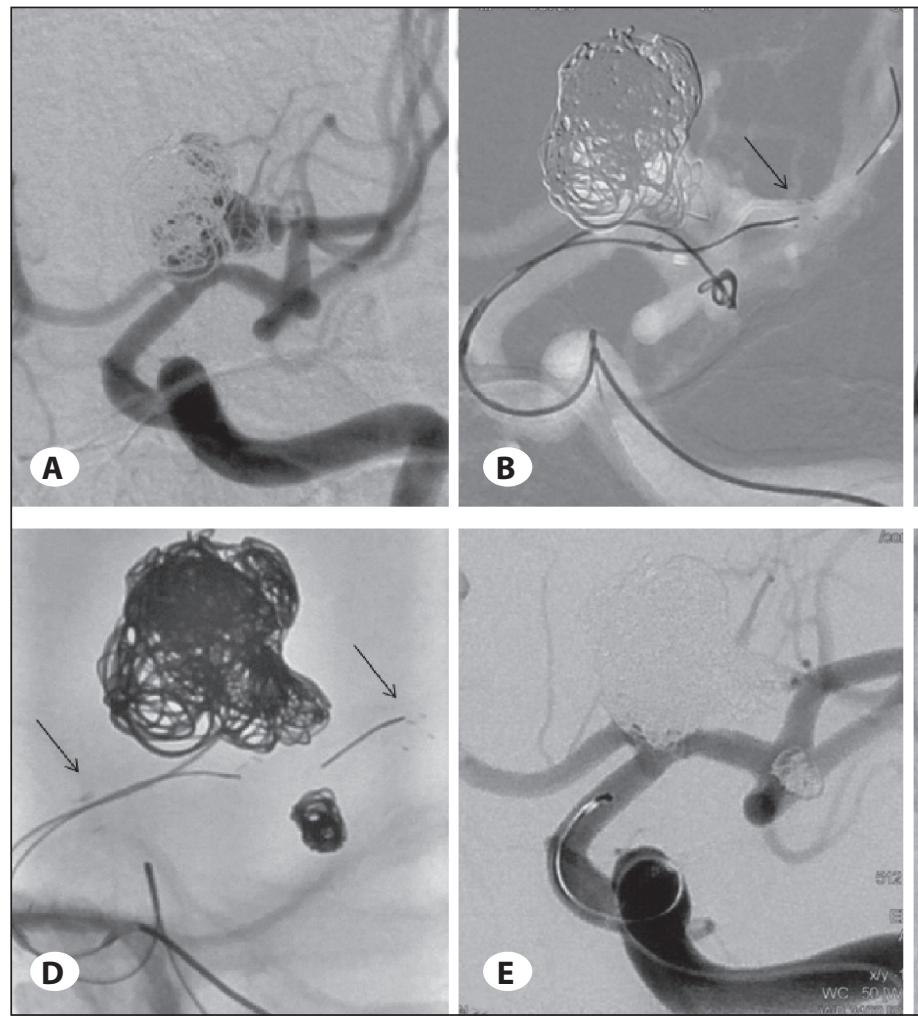

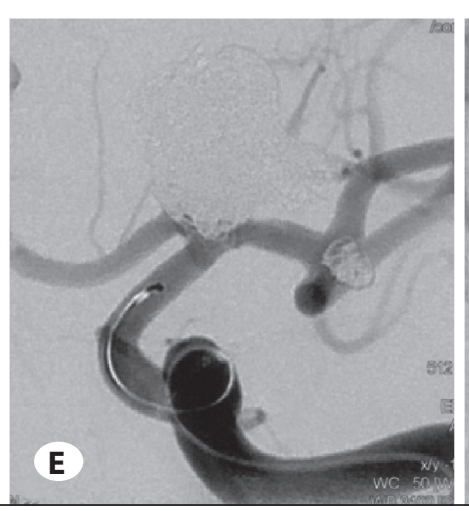

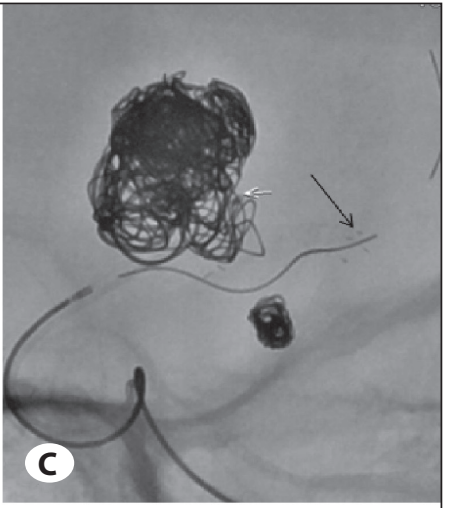

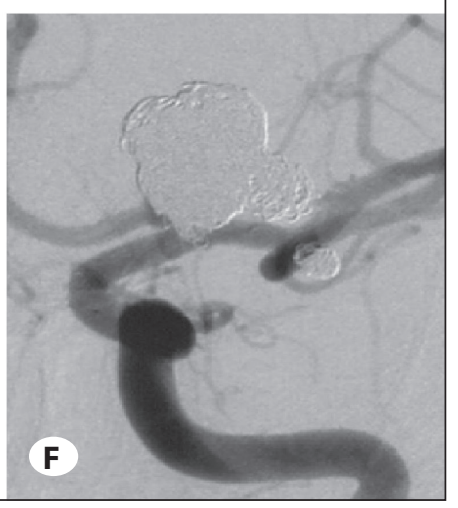

Figure 4 Images of patient 10. Pre-operative angiogram shows a recanalized ICA bifurcation aneurysm and a

concurrent MCA aneurysm (A). The MCA aneurysm is first treated with semi-jailing technique (B). After embolizing the MCA aneurysm, the microcatheter (white arrow) is retreated to the ICA bifurcation aneurysm (C), the stent is then fully deployed to cover the aneurismal neck after introducing part of the coils, additional coils are introduced through the "jailed" microcatheter to embolize the aneurysms (D). Post-operative angiogram shows the aneurysm is completely occluded (E). Angiogram 15 months later shows complete occlusion of the aneurysm with patency of the parent vessels (F). Black arrows show the marker of the stents. 


\section{RESULT}

Characteristics of the 16 patients with complex ICA bifurcation aneurysms, including patient demographics, morphologic features of the aneurysms, treatment results, and follow-up data, are summarized in the Table I.

\section{Initial Embolization Results}

Overall, 16 stents were deployed into the parent arteries, including 10 Enterprise stents, 4 Neuroform stents, 1 Solitarie stent and 1 balloon-mounted coronary stent. Successful stent placement was achieved in all 16 patients, resulting in a technical success rate of $100 \%$.

Of all the 16 aneurysms, five were completely occluded, two had a residual neck, and 9 had a residual sac.

\section{Angiographic Follow-Up}

Angiographic follow-up ranging from 3 to 48 months was available in 15 patients, with a mean of 12.1 months. Four initially occluded aneurysms remain completely occluded. Six aneurysms progressed: four aneurysms with a residual sac and 1 aneurysm with a remnant neck improved to complete occlusion, and one showed decreased contrast filling into the aneurysm sac. Two aneurysms, which were both fusiform, were recanalized. One of them was retreated, overlapping stents were used when retreated, and the aneurysm was improved 7 months after second operation. The other 3 patients $(20 \%)$ remained stable.

Overall, in 15 aneurysms followed up by angiograms, 9/15 $(60 \%)$ of the aneurysms were completely occluded, $1 / 15$ (6.7\%) was improved, 3/15 (20\%) were stable, 2/15 (13.3\%) were recanalized. Parent arteries of the 15 cases were patent with no evidence of intimal hyperplasia or in-stent stenosis.

\section{Clinical Outcome}

SAH-related complication occurred in 2 patients of this series, one was hydrocephalus, and the other was severe vasospasm; however, they both recovered well after treatment of V-P shunt and intra-artery injection of Fasudil respectively. No procedure-related complication occurred.

Clinical evaluation was performed in all patients at discharge by using the mRS scale. All 16 patients were independent with a mRS score of $0-2$ at discharge. All these patients were followed up for 2-123 months (mean, 28.6 months) and none showed any new neurologic deterioration. No aneurysm rebled during the follow-up period.

\section{DISCUSSION}

Internal carotid artery (ICA) bifurcation aneurysms are uncommon, only accounting for about $2 \%-9 \%$ of intracranial aneurysms $(11,16,19,22)$. Clipping is challenging for neurosurgeons due to their deep location, and vital perforators surrounding or adherent to the aneurysms $(8,11,16)$. In one larger series, only $68.6 \%$ (48/70) of the reported patients had favorable outcome (good recovery or moderate disability) (8). Even in patients with good preoperative grade (HH grade I-II), poor outcome (severe disability, vegetative, or dead) occurred in $14.5 \%(7 / 42)$ of the patients. The reasons were premature rupture during surgery, proferators damage or postoperative infarction.

Van Rooij et al ever reported the endovascular treatment for ICA bifurcation aneurysm, and the result was thought to be comparable with surgical results $(7,22)$. However, the aneurysms located at ICA bifurcation often harbor wide necks, which may limit the usage of coiling of the aneurysms $(7,19,22)$. Besides, the fusiform aneurysms are also difficult to be embolized by coils alone.

Now, various "remodeling"techniques had emerged to help overcome these difficulties, such as balloon remodeling, (14) Trispan neck-bridge device, (6) and double microcatheter technique et al. (1). However, most of these remodeling techniques have not changed the hemodynamics of the ICA bifurcation, and may hence accompany with a higher rate of recurrence. Comparatively, intracranial stents seems more promising. It prevents herniation of coils into the parent vessel, increases the packing density, diverts the blood flow, and promotes the reconstruction of the neck of the aneurysms $(4,15,25)$. For ICA bifurcation aneurysm, deployment of stent may also potentially change vascular geometry and decrease hemodynamic stress of the bifurcation (9).

So after intracranial self-expanding stents were introduced into China, we preferred to use stents to treat ICA bifurcation aneurysms. However, until now, articles concerning the usage of stent for ICA bifurcation aneurysms are still few. So we retrospectively collected and analyzed our data of 16 aneurysms with complex morphologies treated by stent-assisted coiling to evaluate the feasibility, safety and effectiveness of stent placement for these particular lesions when using different stents and different stenting strategies.

\section{Selection of stents}

Before the emergence of self-expanding intracranial stents, balloon-expandable stents were used to facilitate embolization of wide-necked aneurysms. However, they have drawbacks for intracranial use due to its poor flexibility and risks related to the usage of balloon. In our series, only 1 such stent was used due to absence of intracranial self-expanding stent at the time of treatment.

Currently, there are 4 types of intracranial self-expanding stents available for treating intracranial aneurysms in China.

The Neuroform stent system (Boston Scientific, Natick, Massachusetts) was the first self-expanding stent designed specifically for treating intracranial aneurysms. It is comparatively easier to navigate and deliver than the balloonexpandable stents; (23) Its open-cell design also make it easier for microcatheter to pass through the intersections of the stents, and may hence facilitate the Y-configuration stent deployment for ICA bifurcation aneurysms when necessary. In the first few years, Neuroform stents were mostly used. However, in recent years, we prefer to use Enterprise stents 


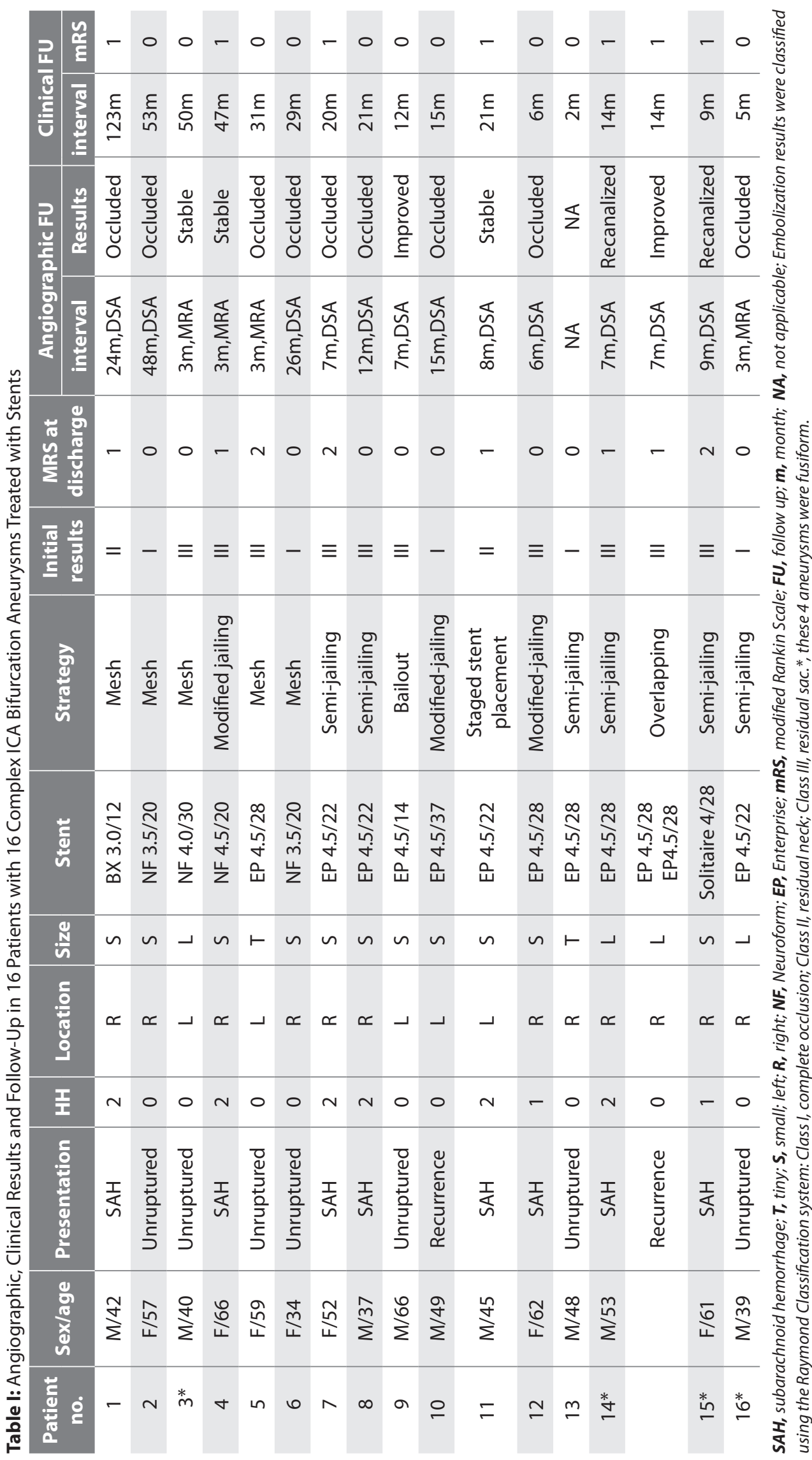


to treat the ICA bifurcation aneurysms. There are 3 reasons: 1) compared with the Neuroform stent, it has a lower profile and higher flexibility; and the close cell design can serve as a better scaffold (25) 2) the enterprise can also be used for Y-configuration stent deployment, which was proved to be feasible and safe (4). 3) since the semi-jailing strategy was preferred in our institution, choosing Enterprise stents, which were retrievable, was imperative. In this group, 10 Enterprise and 4 Neuroform stents were used.

We did not use Leo stent in ICA bifurcation aneurysms since it needs progressively larger profile and stiffer delivery catheters. (13) Besides, its unfixed interstice may be stretched in the curves of ICA bifurcation; this would make the outer surface of the stent and the arterial wall not well contacted. Solitaire ${ }^{\mathrm{TM}} \mathrm{AB}$ stent (ev3, Irvine, CA, USA) is a product recently introduced to China. We have just used one for ICA bifurcation aneurysms.

\section{Selection of stenting strategy}

In this study, we used single stent to treat all aneurysms. For planned stenting, the deployments of the stents were decided based on the location of the aneurysms' necks and the result of neck-pressing tests. For the aneurysms whose necks are dominated on $\mathrm{A} 1$ or $\mathrm{M} 1$, it is undisputable that the stents are deployed into corresponding daughter arteries to assist coiling.

For aneurysms whose necks are symmetrical or predominated on ICA, we choose to deploy the stents into MCA first. Since most of the aneurysms in this series were small in size, the curve of the stent is usually enough to cover most of the aneurysm neck and provide enough support for the coils. However, in some extremely wide-necked aneurysms, single stent may not provide enough support. If the blood flow of A1 is affected during the procedure, subsequent procedure would be considered according to the result of neckpressing tests: If the $\mathrm{A} 1$ segments were compensated well by contralateral blood supply via anterior communicating arteries, additional treatment would be performed since distal ACA can often be supplied well by contralateral blood; otherwise, Y-configuration stent placement would be needed. The Y-configuration stent placement was first introduced to treat basilar aneurysms, (5) and later applied in MCA bifurcation aneurysms (4). Some reports have demonstrated it is feasible and safe to treat bifurcation aneurysms with this technique (20). However, we did not use this technique in this series.

There are also some other reported stenting techniques for bifurcaition aneurysms, such as horizontal stenting, (2) linear-stenting (12) and waffle cone technique (21). The horizontal stenting technique was introduced by Benndorf et al. (2). In this technique, a self-expandable stent was placed horizontally across the aneurysm neck through the anterior communicating artery from contralateral ICA, and then coiling was performed via trans-stent catheterization. The main drawback of this technique was it mandates an adequately sized anterior communicating artery, which may limit its usage. Linear-stenting technique was first introduced in treating wide-necked MCA bifurcation aneurysm (12). In this technique, two self-expandable stents are placed in a"linear" fashion: both stents were delivered within the MCA branches with the aim to have their proximal end facing each other within the bifurcation to completely cover this very wide neck. However, ICA has a larger caliber compared with MCA, the proximal ends of the 2 stents may not completely cover the ICA bifurcation. The other one is waffle cone technique, though it enhanced the possibilities of embolization, it has a high rate of recanalization requiring endovascular retreatment since it potentially divert the blood flow into the aneurysms (21). So we do not recommend to use this technique to treat bifurcation aneurysm.

\section{Safety and Efficacy of Stent Placement in ICA bifurcation aneurysm}

Due to the so-called"water-hammer" effect, ICA bifurcation aneurysms often experienced a high rate of recanalization after coiling. In van Rooij et al's study of 50 coiled aneurysms, the retreatment rate was reported to be $17.5 \%,(22)$ and in the other unpublished data from Geyik et al, the regrowth rate was around $22 \%$ (7).

In the present series, we reported 16 cases which were coiled assisted by stents with no permanent procedurerelated complication occurred. Compared with van Rooij et al's result (near-complete/complete in $94 \%$ of 50 aneurysms and incomplete in $6 \%$ ), complete occlusion rate of our series seems to be lower $(5 / 16)$. This may be due to the complex morphology of these aneurysms. Though dense packing was not always obtained for these complex aneurysms, progressive thrombosis were observed in 5 cases of our series. Totally, $60 \%$ of the aneurysms were cured, $6.7 \%$ was improved, $20 \%$ were stable, $13.3 \%$ were recanalized. This follow-up result is comparable with van Rooij et al's result (recanalization rate, $17.5 \%)$, in which only 4 were widenecked, (22) and also consistent with other reports about the usage of stent, recanalization rate for the stent assisted coiling of the aneurysms was $18.9 \%$ in Kim's article, $19.4 \%$ in weber's, and $20 \%$ in Biondi's $(3,10,25)$.

Fusiform aneurysms in anterior circulation are mainly located ICA $(18,24)$. These aneurysm used to be treated via a "destructive" approach, such as trapping, parent artery occlusion, or surgical resection followed by function bypass. However, the complications are thought to be high in most reports $(18,24)$. In recent years, reconstructive approach is preferred to treat these aneurysms, and reported to be safe and effective (24). Fusiform ICA bifurcation aneurysms are rare, most of them extended from ICA to MCA. In this series, we used stent to reconstruct the vessels, all of them were successfully treated. However, fusiform aneurysms seem to harbor a higher recanalization rate.

When stents are used, complications include thrombosis during or after the procedure, delayed in-stent stenosis, 
occlusion of perforators surrounding or originating from the aneurysms, procedure-related hemorrhage, and et al. However, in most studies of recent years, the complication rates were found to be acceptable $(3,4,25,26)$. In this series, we did not encounter any of these complications either.

In previous articles concerning the patients receiving endovascular treatment, about $80 \%(37 / 46)$ of the patients harboring ICA bifurcation aneurysms in van Rooij et al's article had good outcomes (22). This rate is comparable with that of patients who were clipped in 2 larger series (59\% in Miyazawa et al's series and $69 \%$ in Gupta et al's) $(8,16)$. Our data suggests that stent placement for ICA bifurcation aneurysms also seems to be safe. No procedure-related complications occurred, and none showed any new neurologic deterioration during the follow-up period.

\section{Limitations}

The limitations of this study include its retrospective design, patient-selection bias, limited cases in one single institution, and the inadequate angiographic follow-up. However, to our knowledge, this is the largest series for stent placement in ICA bifurcation aneurysms to date.

\section{CONCLUSIONS}

Our result suggests that stent placement for the treatment of complex ICA bifurcation aneurysms is feasible and safe. However, its efficacy should be further evaluated by larger case series and more adequate follow-up..

\section{ACKNOWLEDGEMENTS}

This work was supported by the National Natural Science Foundation of China (81000494), the dawn project of shanghai (11CG043), and Science and Technology Commission of Shanghai Municipality (10441901902).

\section{REFERENCES}

1. Baxter BW, Rosso D, Lownie SP: Double microcatheter technique for detachable coil treatment of large, widenecked intracranial aneurysms. AJNR Am J Neuroradiol 19:1176-1178, 1998

2. Benndorf G, Klucznik RP, Meyer D, Strother CM, Mawad ME: "Cross-over" technique for horizontal stenting of an internal carotid bifurcation aneurysm using a new self-expandable stent: Technical case report. Neurosurgery 58:ONS-E172; discussion ONS-E172, 2006

3. Biondi A, Janardhan V, Katz JM, Salvaggio K, Riina HA, Gobin YP: Neuroform stent-assisted coil embolization of wide-neck intracranial aneurysms: Strategies in stent deployment and midterm follow-up. Neurosurgery 61:460-468; discussion 468-469, 2007

4. Cekirge HS, Yavuz K, Geyik S, Saatci I: A novel "Y" stent flow diversion technique for the endovascular treatment of bifurcation aneurysms without endosaccular coiling. Am J Neuroradiol 32:1262-1268, 2011
5. Chow MM, Woo HH, Masaryk TJ, Rasmussen PA: A novel endovascular treatment of a wide-necked basilar apex aneurysm by using a Y-configuration, double-stent technique. Am J Neuroradiol 25:509-512, 2004

6. De Keukeleire K, Vanlangenhove P, Defreyne L: Evaluation of a neck-bridge device to assist endovascular treatment of wideneck aneurysms of the anterior circulation. Am J Neuroradiol 29:73-78, 2008

7. Geyik S, Yavuz K, Cekirge S, Saatci I: Endovascular treatment of basilar and ICA termination aneurysms: Effects of the use of HydroCoils on treatment stability in a subgroup of patients prone to a higher recurrence rate. Neuroradiology 49:10151021, 2007

8. Gupta SK, Khosla VK, Chhabra R, Mohindra S, Bapuraj JR, Khandelwal N, Mukherjee KK, Tewari MK, Pathak A, Mathuriya SN: Internal carotid artery bifurcation aneurysms: Surgical experience. Neurol Med Chir (Tokyo) 47:153-157; discussion 157-158, 2007

9. Huang QH, Wu YF, Xu Y, Hong B, Zhang L, Liu JM: Vascular geometry change because of endovascular stent placement for anterior communicating artery aneurysms. Am J Neuroradiol 32:1721-1725, 2011

10. Kim DJ, Suh SH, Lee JW, Kim BM, Huh SK, Kim DI: Influences of stents on the outcome of coil embolized intracranial aneurysms: Comparison between a stent-remodeled and non-remodeled treatment. Acta Neurochir (Wien) 152: 423-429, 2010

11. Lehecka M, Dashti R, Romani R, Celik O, Navratil O, Kivipelto L, Kivisaari R, Shen H, Ishii K, Karatas A, Lehto H, Kokuzawa J, Niemela M, Rinne J, Ronkainen A, Koivisto T, Jaaskelainen $\mathrm{JE}$, Hernesniemi J: Microneurosurgical management of internal carotid artery bifurcation aneurysms. Surg Neurol 71: 649-667, 2009

12. Lubicz B: Linear stent-assisted coiling: Another way to treat very wide-necked intracranial aneurysms. Neuroradiology 53:457-459, 2011

13. Lubicz B, Francois O, Levivier M, Brotchi J, Baleriaux D: Preliminary experience with the enterprise stent for endovascular treatment of complex intracranial aneurysms: Potential advantages and limiting characteristics. Neurosurgery 62:10631069; discussion 1069-1070, 2008

14. Lubicz B, Lefranc F, Bruneau M, Baleriaux D, De Witte O: Balloon-assisted coiling of intracranial aneurysms is not associated with a higher complication rate. Neuroradiology 50:769-776, 2008

15. Lv X, Li Y, Xinjian Y, Jiang C, Wu Z: Results of endovascular treatment for intracranial wide-necked saccular and dissecting aneurysms using the enterprise stent: A single center experience. Eur J Radiol 2011

16. Miyazawa N, Nukui H, Horikoshi T, Yagishita T, Sugita $M$, Kanemaru K: Surgical management of aneurysms of the bifurcation of the internal carotid artery. Clin Neurol Neurosurg 104:103-114, 2002 
17. Molyneux AJ, Kerr RS, Yu LM, Clarke M, Sneade M, Yarnold $J A$, Sandercock P: International subarachnoid aneurysm trial (ISAT) of neurosurgical clipping versus endovascular coiling in 2143 patients with ruptured intracranial aneurysms: A randomised comparison of effects on survival, dependency, seizures, rebleeding, subgroups, and aneurysm occlusion. Lancet 366:809-817, 2005

18. Ohkuma H, Suzuki S, Ogane K: Dissecting aneurysms of intracranial carotid circulation. Stroke 33:941-947, 2002

19. Sakamoto S, Ohba S, Shibukawa M, Kiura Y, Okazaki T, Arita $\mathrm{K}$, Kurisu K: Characteristics of aneurysms of the internal carotid artery bifurcation. Acta Neurochir (Wien) 148:139-143; discussion 143, 2006.

20. Spiotta AM, Gupta R, Fiorella D, Gonugunta V, Lobo B, Rasmussen PA, Moskowitz SI: Mid-term results of endovascular coiling of wide-necked aneurysms using double stents in a $Y$ configuration. Neurosurgery 69:421-429, 2011

21. Sychra V, Klisch J, Werner M, Dettenborn C, Petrovitch A, Strasilla C, Gerlach R, Rosahl S, Holtmannspotter M: Wafflecone technique with Solitaire $A B$ Remodeling Device: Endovascular treatment of highly selected complex cerebral aneurysms. Neuroradiology 53:961-972, 2011
22. van Rooij WJ, Sluzewski M, Beute GN: Internal carotid bifurcation aneurysms: Frequency, angiographic anatomy and results of coiling in 50 aneurysms. Neuroradiology 50:583-587, 2008

23. Wajnberg E, de Souza JM, Marchiori E, Gasparetto EL: Singlecenter experience with the Neuroform stent for endovascular treatment of wide-necked intracranial aneurysms. Surg Neurol 72:612-619, 2009

24. Wakhloo AK, Mandell J, Gounis MJ, Brooks C, Linfante I, Winer J, Weaver JP: Stent-assisted reconstructive endovascular repair of cranial fusiform atherosclerotic and dissecting aneurysms: Long-term clinical and angiographic follow-up. Stroke 39:3288-3296, 2008

25. Weber W, Bendszus M, Kis B, Boulanger T, Solymosi L, Kuhne D: A new self-expanding nitinol stent (Enterprise) for the treatment of wide-necked intracranial aneurysms: Initial clinical and angiographic results in 31 aneurysms. Neuroradiology 49:555-561, 2007

26. Yang P, Liu J, Huang Q, Zhao W, Hong B, Xu Y, Zhao R: Endovascular treatment of wide-neck middle cerebral artery aneurysms with stents: A review of 16 cases. Am J Neuroradiol 31:940-946, 2010 